\title{
Partnership and conflict between parents and schools: How are schools reacting to the new participation law in Flanders (Belgium)?
}

The final publication is available at http://www.tandfonline.com/toc/tedp20/current\#.VCpxIRY09DU

DOM, L. \& VERHOEVEN, J. C. (2006) "Partnership and conflict between parents and schools: how are schools reacting to the new participation law in Flanders (Belgium)" Journal of Education Policy 21 (5) pp. 567-597. DOI: $10.1080 / 02680930600866132$

Leen Dom \& Jef C. Verhoeven 
Partnership and conflict between parents and schools: How are schools reacting to the new participation law in Flanders (Belgium)?

\section{Leen Dom}

Centre for Sociology of Education,

University of Leuven,

E. Van Evenstraat 2b,

3000 Leuven

Belgium

E-mail: leen.dom@soc.kuleuven.be

Phone: 0032(0)16 323206

Fax: 0032(0)16323365

\section{Jef C. Verhoeven}

Centre for Sociology of Education,

University of Leuven,

E. Van Evenstraat 2b,

3000 Leuven

Belgium

E-mail: jef.verhoeven@soc.kuleuven.be

Phone: 0032(0)16 323205

Fax: 0032(0)16323365

\section{Abstract:}

This paper explores the relationship between parents and schools. Over the last 30 years, the importance attached to parents' views on education has increased significantly throughout in the Western world.

Policy-makers encourage parental participation and involvement through the creation of councils in which parents have a say. In Flanders in Belgium in 2004, a new participation law was passed. We study the impact of this law on the micropolitical relations between parents, school heads, and teachers. In four primary schools, we conducted in-depth interviews with teachers, parents, school heads, and members of the organizing body and observed parents' gatherings. Starting from the partnership-conflict opposition, we focus on the functioning of the parents' associations and the way parents' associations, school heads, 
and teachers are dealing with this new law. We found that the parent-school relationship differs greatly from school to school. While the socio-economic middle-class predominates in the four parents' associations, the results show that the parental empowerment is enhanced only in the schools with mainly socio-economically weak families. 


\title{
Partnership and conflict between parents and schools: How are schools reacting to the new participation law in Flanders (Belgium)?
}

\author{
Leen Dom \& Jef C. Verhoeven
}

\section{Introduction}

Over the last 30 years, the role of parents in the educational structure has changed dramatically. This process has taken place not only in Belgium but throughout the entire Western world. Parents' opinions about the education of their children are being taken more and more seriously, and parents are becoming increasingly involved in their children's schooling. In recent years in many countries, schoolbased management and lay participation in local school policy-making have developed (Deem 1994: 35). This evolution commenced in Belgium in the 1970s. The economic recession at the time brought the realisation that the educational system needed to be profoundly reformed and led to democratization of the educational system as well as of the curriculum. This trend continued through the 1980s. The decrease in the number of pupils was accompanied by cuts in funding and structural policy measures. Meanwhile, the confidence people had in education and in teachers declined, which led to a growing demand on the part of parents and teachers to participate in the formation of educational policy. Participation and coresponsibility became features of the 'effective school' (Mahieu 1988). Since then, the involvement of parents in education has gradually increased.

We cannot yet speak in Flanders (1) - as in the Anglo-Saxon world - of a 'parentocracy' (Brown 1990), but the trend to greater parental involvement is obvious. The first legislation on the formal involvement of parents went into force in 1988 with the establishment of the local school councils in the community network of schools (2) (Van Heddegem and Verhoeven 1998, Verhoeven and Van Heddegem, 1999). In 1998, these local school councils were abolished and replaced by school councils consisting of representatives of parents and teachers and co-opted members from the local community. The school head is not a member of the school council but attends the meetings and has an advisory voice. The chairperson of the school council is elected from the representatives of the parents or the coopted members. Participation of parents in grant-aided official and grant-aided free schools started in 
1991. The Decree of 23 October 1991 established a participatory council in each school. These councils consisted of representatives of the organizing body, the parents, the staff members, and the local community. In general, the school head was the chairperson of the participation council. The differences between the school councils and participation councils were subtle but still important for the parties involved. In the participation councils, the school head and representatives of the organizing body were formal members whereas in the school councils they were not. The responsibilities of the two councils also differed slightly.

Recently, in April 2004, a new participation law was passed. This law was intended to increase the involvement in school policy of school heads, teachers, pupils, and parents. The responsibilities of the school council were expanded, and the informal school-related parents' associations were formalized. The law replaced the participation councils in the grant-aided school networks by school councils as they already existed in the community school network. The main difference between the composition of the participation council and that of the school council is that the school's organizing body was represented in the participation council while in the school council it is not. In addition, the law created the possibility of establishing a 'parents' council', 'a staff council', and a 'student council'. For our research, the parents' council is of primary concern. The establishment of the parents' council is not compulsory unless at least $10 \%$ of the parents in the school demand it. If a parents' council is established, members of the parents' council are elected to represent the parents in the school council, the idea being to assure continuity between the parents' and the school council. Unlike the parents' association, the parents' council has an official legislative raison d'être. Not all of the reactions to this new participation law were positive. The umbrella organization of the Catholic schools, Vlaams Secretariaat voor het Katholieke Onderwijs (VSKO, the Flemish Secretariat for Catholic Education) had fundamental objections to the decree. Because the Catholic schools are by far the most numerous schools in the grant-aided free network and because more than $60 \%$ of the primary and secondary schools in Flanders are grant-aided free schools, it was not surprising that the VSKO's opinion weighed considerably in the debate. The main problem the VSKO had with the decree was not the legislative grounding of the participation of teachers, students, and parents in school policy. However, the VSKO was against too much formalization of that participation. The VSKO, therefore, preferred to grant parents a 'participation right' rather than a 'participation duty'. 
The second important objection of the VSKO was that the school's organizing body was no longer represented in the school council. We will see later on that these points of view influenced the school practices. In table 1 the different councils are lined up. All the councils' members except for the school head are elected or co-opted volunteers.

[Insert table 1 about here]

Policymakers are usually positive about parental involvement and parental participation in schools. This appraisal is influenced by the supposed positive impact of parent involvement on academic achievement. Nevertheless, the results of previous research of the effects of parent involvement on student outcomes (see, for example, Stevenson and Baker 1987, Fehrmann, Keith and Reimers 1989, White, Taylor and Moss 1992, Ho and Willms 1996, Griffith 1996, Desimone 1999, Feuerstein 2000, Peña 2000, Sheldon and Epstein 2005) are inconsistent due to several factors (3). In spite of these inconsistencies, policymakers often cite the positive impact of parental involvement. In the daily life of the school, however, parental participation is not always self-evident. According to Vincent (1996), the debate about home-school relations is often superficial. One of the reasons for this superficiality is 'the reliance on consensual language, such as "partnership", "dialogue", "involvement", "sharing” which features strongly in the home-school literature' (Vincent 1996: 73). These terms suggest a 'warm community-spirit', which is not always achieved in real life. In reality, parent involvement is a more diverse and complex concept than is generally acknowledged (Crozier 2000). In fact, the relationship between parents and schools (school heads and teachers) is often characterized by power struggles instead of partnership. In this respect, Lareau $(1989,1997)$ mentions 'the dark side of parent involvement'. Too much involvement of parents can make children feel insecure and create fear of failure, and parent involvement can have negative consequences on the school's organisational dynamics and especially on the role of the teacher. Moreover, parental involvement is often led by individualistic motives (Vincent and Martin 2000).

\section{Partnership or conflict?}


The relationship between parents and schools is thus not as straightforward as it might appear at first sight. The question is why? Why do parents and teachers or school heads sometimes seem to conflict rather than to connect? In the search for the answer, we turn to negotiation theory (Strauss 1978) and the theory of micropolitics (Ball 1986; Blase 1991). Indeed, negotiation, power, and balances of power are important factors in the relationship between the parents and the teachers/school heads.

Negotiation theory and micropolitical theory are similar in many regards. Both perspectives start from the idea of the organization in process and take organizations to be arenas within which actors have their own agendas. According to negotiation theory (Strauss 1964, 1978), the social order is a negotiated order. There can be no organizational relationship without accompanying negotiations. Negotiation is one of the possible means for 'getting things accomplished' (Strauss 1978: 11). The negotiated order on any given day can be conceived of as 'the sum total of the organization's rules and policies along with whatever agreements, understandings, pacts, contracts and other working arrangements currently obtained' (Strauss 1978: 5). The negotiated order is not a fixed order. Any changes impinging on the negotiated order call for renegotiation or reappraisal, and larger structural considerations need to be taken into account when studying negotiation processes. Changes in structural conditions affect the process of negotiation as new types of negotiation contexts may evolve while old ones may disappear. In addition to this structural context 'within which' negotiations take place in the largest sense, Strauss (1978: 237-238) describes the 'negotiation context', 'the structural properties entering very directly as conditions into the course of negotiation itself: 'the number of negotiators, their relative experience in negotiating and who they represent'; 'the relative balance of power exhibited by the respective parties in the negotiation itself'; 'the nature of the respective stakes in the negotiation'; 'the visibility of the transactions to others', and so on.

According to micropolitical theory (Ball 1986; Blase 1991), schools are typically characterized by a lack of consensus of the members of the organization about the intention of their interactions. This is related to the way the organization is structured. The school's structure reproduces dissensus and goal diversity. The autonomy of all the subunits in the educational organization results in what Bidwell (1965: 978) calls 'structural looseness'. Schools are 'loosely coupled systems' (Weick 1976) in which all the members - teachers, school heads, and parents - have space for political activity. Moreover, in the 
micropolitical perspective, schools are conceived as 'arenas of struggle': 'to be riven with actual or potential conflict between members; to be poorly co-ordinated; to be ideologically diverse' (Ball 1986: 19). This does not mean that conflict is always present in the school. Most of the daily interactions in the school are routine and thus far from discordant. But there is always a chance that power struggles between members will result in conflicts, and it is through these struggles and conflicts that organizations grow and develop. Micropolitics, according to Blase (1991: 11), 'refers to the use of formal and informal power by individuals and groups to achieve their goals in organizations. In large part, political actions result from perceived differences between individuals and groups coupled with the motivation to use power and influence and/or protect. Although such actions are consciously motivated, any action, consciously or unconsciously motivated, may have political "significance" in a given situation. Both cooperative and conflictive actions are part of the realm of micropolitics'.

If we apply these perspectives to the relations between parents, teachers, and school heads, we come to the following conclusions. School heads, parents, and teachers are all actors in the school's 'negotiated order'. Traditionally, teachers and parents have different interests to defend or, in negotiation terms, different 'things to get accomplished'. The universalistic perspective of the teacher - who is responsible for a group of children - clashes with the parents' individualistic perspective - their own child. Already in the 1930's, Waller (1932, reissued 1961) called teachers and parents 'natural enemies' because of this difference in perspective. Moreover, teachers see themselves as 'professionals' and are accustomed to a large degree of autonomy in their own classroom. Parents' respect for the professionalism of teachers is considered very important by the teacher. Teachers usually think that parents should keep their distance and know their place as they themselves do with regard to other professionals (Crozier 2000: 117).

In a study on the well-being of Flemish teachers, Aelterman et al. (2002a: 92) found that, on average, elementary school teachers were rather pleased with their relationships with parents. However, although teachers were willing to cooperate with parents, they were sometimes sceptical about these contacts. Many teachers did not appreciate the involvement of some parents, but they also did not want parents to be indifferent to their children's progress in school (Aelterman et al. 2002a: 53). Traditionally, the school is the teacher's domain. The teachers wanted parents to be involved with their children's' schooling but they did not want 'a partnership' with parents. Lareau (1989: 35) found that teachers did not 
want to be equals with parents. Instead, they wanted parents to defer to them and to their decisions in the classroom. Rather than a partnership, a more accurate term for what teachers wanted would be a 'professional-client' relationship.

Starting from micropolitical theory, we could say that the professionalism of teachers is a source of power. Through their education and professional training, teachers acquire a certain amount of 'expert knowledge' that can be used to keep parents at a distance. However, professionalism is an elastic concept. Hargreaves (2000) talks about 'the post-professional' or 'post-modern age' that has led to a 'deprofessionalisation' among teachers. 'Schools (and teachers) are losing their monopoly on learning, as students and parents can access more and more information independently from them' (Hargreaves 2000: 172). Professionalism also has an emotional meaning. That it is objectively decreasing- that the autonomy of teacher is diminishing - does not automatically mean that teachers no longer see themselves as professionals.

In Flanders, research indicates that a large part of the educational staff perceives an imbalance between the increasing social expectations from teachers, their professional self-image, and the social appreciation of what they do (Aelterman et al. 2002b). Teachers are feeling under-appreciated by society. Some researchers call this the 'proletarianisation' of teachers (Densmore 1987, Ozga and Lawn 1988, Calgren 1999, Crozier 2000). All this makes teachers more vulnerable in their relationship to parents (Kelchtermans 1996). From the experiences they have along their career, teachers develop a specific way of seeing themselves as a teacher: their 'professional self. If parents question this professional self, for example, through criticism, teachers feel vulnerable, and this vulnerability increases as their professional activities become more and more visible. Their working conditions can be characterized by living in a fishbowl' (Blase 1987).

According to Chen (2003), 'particularly with the introduction to parental participation in schoolbased management in the first instance there is a tension between the teacher professionalism and the forces of parental empowerment regarding the processes of school decision-making'. Chen finds that 'the relations between teacher delegates and parent representatives in the school-based decision-making committee were tensional'. 
While teachers commit their professionalism and expert knowledge, parents put in their own resources. One could say that the parent as a client would be in a subordinate, less powerful position compared to the teacher as a professional. However, several ethnographic studies (for example, Lareau 1989, Reay 1998, Birenbaum-Carmelli 1999, Ball and Vincent 2000) have shown parents applying their social, economic, and cultural resources to press their own agenda on schools. Parents are the ones that are able to call the teachers to account. They can use their 'voice' to articulate their critical opinions and to influence school operations when they are dissatisfied with the services received. If the school fails to improve sufficiently, they can choose the 'exit-option' (Goldring and Hausman 1999, Crozier 2000) and enrol their children elsewhere.

The availability of expert knowledge has grown significantly, and parents themselves are increasingly becoming themselves experts in their children's' education. Because the social position of teachers is diminishing, teachers often feel insecure in their relationship with more 'prestigious' parents (Lareau 1989, Birenbaum-Carmelli 1999). By 'prestigious' parents, we mean parents from the upper middle classes. Indeed, not all parents have equal resources in their relationship with teachers. The parents' social, economic, and cultural capital matters. The socio-economic status of parents has a direct impact on the resources parents can bring into their relationship with the school. The higher the status, the more resources parents can bring to their demands.

Socio-economic status or social class is thus a differentiating factor in the relationship between parents and schools. Several studies, mostly ethnographic (among others, Crozier 2000, Lareau 1989, Reay 1998, Van Zanten 2002, Verhoeven and Kochuyt 1995, Vincent 2001,Vincent and Martin 2000, and Vincent and Martin 2002), have related parents' social class to their involvement with the school of their children. Differences are marked in the actions between middle-class parents versus those of workingclass parents (Crozier 2000, Lareau 1989, Reay 1998), between different middle-class (Vincent 2001) and working-class groupings (Van Zanten 2002), and between working-class parents and parents of the underclass (Verhoeven and Kochuyt 1995). Class or social class is 'a term used to differentiate the population on grounds of economic considerations, such as inequality in terms of wealth or income' (Bilton, Bonnett, Jones, Skinner, Stanworth and Webster 1996: 138). The differences between the middle and working classes can be explained on the basis of their different market capacities. 'Different labour 
market capacities bring in turn different levels of reward which then produce inequalities in all areas of life: conditions at work, health, housing, education, mortality and justice' (Bilton et al. 1996: 155). The differences in income, patterns of work and life-cycle of earnings result in very different life opportunities between the more affluent middle and less well-off working classes (Bilton et al. 1996: 158). The underclass, then, is 'the group located at the bottom of the social hierarchy who are economically, politically and socially marginalised from the rest of society' (Bilton et al 1996: 148). Changes in the occupational labour market and in society in general during the previous decades have resulted in a reduction of the capacity of social reproduction of the working and middle classes. In late modernity (Giddens 1991), class identities have become more difficult to reproduce over generations. Class identity has become less central in people's lives and is derived more and more from what people consume than by the work they do. However, the opportunity to be a consumer will ultimately depend on one's opportunity to secure income, which, for many, is still related to the job they do (Bilton et al. 1996: 195).

Socio-economic status thus influences the relationship between parents and teachers or school heads. Important in this respect is that the differences are not due to a lack of interest of parents of lower socio-economic status: 'just about all parents care about their children's progress and success in school.... The myth of parental indifference has been debunked in study after study in this and other nations' (Epstein 2001: 161). All parents, including working-class parents (Crozier 2000) and underclass parents (Verhoeven and Kochuyt 1995), support their children. Their support, however, is less visible to the school than the support of middle-class parents. Lareau (1989: 9) finds that working-class parents lacked both the skills and the confidence to help their children at school. Middle-class parents are more visible at school and intervene more openly than do working-class parents (Crozier 2000). According to Reay (1998: 70), the support of working-class women 'was not invested with the certainty of the middle-class women's interventions'. Moreover, the parents' status influences the content of the conflicts between parents and teachers (Lareau 1989). Working-class parents rarely have complaints about the school, and, when they do complain, it usually is about non-academic matters such as discipline. The complaints of higher middleclass parents are centred more on aspects of the professional expert knowledge and specifically on teaching ability. 
As a consequence of all this, the relationship between parents and teachers is characterized by a struggle for control. Teachers 'have two broad sets of relationships to manage: with the assertive, demanding middle-class parents on the one hand and with the seemingly passive, disengaged workingclass parents on the other' (Crozier 2000: 123). This means the struggle between middle-class parents and teachers is more balanced, although Crozier (2000: 124) finds that 'the middle-class parents often have the upper hand. The contest between the working-class parents and the teachers, however, has been seen to be unequal with the working-class parents being aware of this and thus, frequently, opting out'. Nevertheless, it should be noted that different approaches to education are found by different middleclass (Vincent 2001) and working-class groupings (Van Zanten 2002).

We have yet to speak of the third party involved, the school head. In the negotiations between parents and teachers, the school head plays an important role. He or she determines for a large part the structural conditions in which the teachers and parents act: school climate, school policy, school view, and so on. The school head has a crucial role in determining the degree and efficacy of parental involvement at school (Goldring and Shapira 1996: 344). A good relationship with parents contributes to an effective school and thus is important for the school leader. Effective principals are characterized by the willingness to share their power while ineffective principals exhibit a reluctance to relate to parents and the community (Teddlie and Stringfield 1993). The school head also influences the actions of the teachers. Teachers often develop patterns of social interaction as an immediate reaction to the way the school head leads them (Blase 1987, Blase and Anderson 1995). In the interactions between teachers and parents, the support the school head provides is very important. From a micropolitical perspective, the support of the school head increases the discretion and authority of teachers and also their capacity to influence parents. Moreover, when school heads support their teachers, parents react more positively and rationally to the school and the school's expectations. Conversely, lack of support from school heads influences the micropolitical orientation of teachers negatively. It is difficult for teachers to deal with irrational or troublesome parents if these parents perceive that the school head does not support the teachers.

\section{Research question}


You are taking your child to school for the first time. As you enter the school gate you see other mothers. They seem to have arranged themselves in a rough line facing the school. The school head appears on the steps. A ripple of movement passes through the group and you see that there is a line - it is painted on the playground. Below is a message, probably your first communication from the school. It reads, "No parents beyond this line"” (Green 1970: 11).

In 1966 in the United Kingdom, parents were kept away from school by means of a white chalk line on the playground. Nowadays, there are no longer any schools in which parents are literally stopped from entering the school building. However, in each school there remains a line parents are not allowed to cross. In each school, there is a field for which parents can and may be responsible and a field that the school - teachers and school head - controls. All the parties devote resources to guard this line. Every so often, one of the parties tries to move the line, which may give rise to objections by the others. After negotiations between the parties, the line may be moved. Sometimes the line is unclear, and actors may unwittingly cross it. When this happens, the other actors may stand up and protest, which makes the line visible. The line is located differently in each school. Moreover, the line can move from moment to moment and not be the same for every actor. From the teachers' point of view, we can speak of a 'professionalism barrier' that keeps parents at a distance and works in an exclusionary and undemocratic way (Crozier 2000: 90). From the parent's side, not all parents have the same ability to cross this barrier, and their social background plays an important role.

In this paper, we investigate how negotiation about this hypothetical line takes place in the school. The purpose is to explore how different schools handle this line. We also want to see what happens with the negotiation process when change, namely the new participation decree in Flanders, is forced. How do the different parties deal with this new reality? Is this law producing structural changes or is everything kept intact?

We will look at the schools in function of the theoretical question of different levels of 'partnership or conflict'. Proceeding from the theoretical perspective outlined above, we assume the relations between parents and teachers and school heads could be described as conflictual rather than as a partnership. However, this is not a hypothesis in the narrow sense of the word. Instead of testing it, we want to start from the opposition 'partnership or conflict' and look for elements of partnership or conflict 
in the schools. To investigate the relationship between the parents and the school in micropolitical terms, we will look primarily at the relationship between the parent's association and the school. The parents' association often is the only grouping of parents in a school. Usually it is this association that defends the rights of parents and children in the school. Parents' associations often act as interest groups and use their power to look after their own interests. Therefore, parents' associations are originally 'political' organizations. As a consequence of this 'political' origin of parents' associations, it can be assumed that the actions of members of these associations have micro-political intentions. In the relationship between the parents' association and the school, we can find structural conflicts or structural elements of partnership that cannot be found in the individual relationships between parents and teachers or school heads. In the picture of how the school functions as an organization, these structural elements are much more interesting than individual elements.

\section{Methodology}

The case-study method was used to respond to these research questions. We used 'theoretical sampling' to select the cases (Strauss and Corbin 1991). This means that cases were selected on the basis of concepts that have proven theoretical relevance to the evolving theory. Theoretical sampling does not attempt to generalize as such to a larger population but rather to specify (Strauss and Corbin 1991: 191).

Prior to the selection of the cases, we had already decided to do research in elementary education. This choice was motivated by the following considerations. First, earlier research in Flanders (Verhoeven et al. 2003) indicated that parents of young children (6-12 year olds) are more involved in education and are less 'hindered' by rejective behaviour of their children than parents of secondary school students. Besides, the physical distance between home and school is usually small in elementary education so the chance of interaction between parents and teachers or school heads is great. Moreover, teachers in elementary education have a much more profound contact with their pupils than do secondary school teachers because they only teach one group of children. We limited our research to native Belgian parents because involvement of immigrant parents would be affected by very specific cultural and linguistic elements that would interfere with the comparability of the material. 
Given these limitations, we used two criteria to select the schools, the first being the size of the school. Because we wanted to study the contact parents had with the school, school size could make a difference. In large schools, the contact between parents and school would be less personal than in small schools. We also distinguished between schools with a large population of underprivileged children and those with a small population of underprivileged children in order to reach parents of a different socioeconomic status. This way, we aimed at including parents from different social strata in our research: parents from the most vulnerable social groups as well as upper middle-class parents were interviewed. As the indicator for socio-economic status, we used the professional status of the parents. Because in Belgium there are no homogeneous middle-class or working-class schools, we distinguished between schools based on the proportions of underprivileged pupils in the school. We restricted our selection to one city in order to exclude regional differences.

Concretely, we selected four elementary schools in a large city (about 500000 inhabitants) in Flanders: a small school (188 pupils) (4) with many underprivileged children, (5) a large school (377 pupils) with many underprivileged children, a small school (230 pupils) with few underprivileged children, and a large school (400 pupils) with few underprivileged children. In each school, we interviewed parents (members of the parents' association as well as non-members), teachers, the school head, a representative from the organizing body of the school, and a staff member from the school's centre for educational guidance. We also used participatory observation to study the functioning of the parents' associations and - if present in school - the mother's group, (6) the participation council, and the parents' council. The fieldwork took place over a period of two academic years (September 2003 - June 2004 and September 2004 - June 2005). In total, we conducted in-depth interviews with 66 parents, four chairpersons of the parents' association, and one chairperson of the new parents' council. We interviewed 29 teachers. The four school heads were interviewed twice. In addition, four representatives of the school's organizing body and four staff members of the school's guidance centre were interviewed. In each school, we attended a meeting of the parents' association, and one of the mother group (present in one school), the participation council (in two schools), and the new parents' council (in two schools). The interviews were transcribed and analysed with QSR N-Vivo. During the period of this study, a new participation law was 
enacted. This gave us the opportunity to examine how each of the four schools handled the implementation of this law.

\section{Cases}

Before discussing the reactions of the schools to the new participation law, we will briefly describe the schools and the way the relationship with the parents has taken shape. As outlined above in the section on the research question, we will start from the differences in the relationship between the parents' association and the school and then describe the schools in function of the elements of partnership and conflict we detected.

\section{The Triangle School}

The Triangle School (7) is a grant-aided free school. With 360 pupils it is a rather large school. The school is located in a fairly quiet neighbourhood on a tree-lined avenue. When you pass through the main entrance, the school head's office is immediately on the left. Through a long corridor you arrive at the playground around which the classrooms are situated. The pupils wear blue and white uniforms. Most of the pupils live in the immediate vicinity of the school, and immigrant families are increasingly taking up residence in this neighbourhood. All social strata are represented, but there is a clear presence of children from lower social strata and an increasing number of immigrant children. About $40 \%$ of the school population are immigrant children. Most of the parents are low-level white-collar employees, and more or less 15\% are unemployed. The last three school years, the Triangle School had three different school heads. In 2003-2004, the first year of the fieldwork, Annie Mertens, a teacher at this school, became the temporary school head in anticipation of the new school head who was to be appointed in September 2004 (8). 
The Triangle's parents' association consists of ten members. It is a rather small but very active committee that organizes a number of activities such as an annual Christmas market, a quiz, a cultural activity, and so on. However, the parents' association wants to do more than merely organize events:

We want to put across the voice of the parents to the school, so the things they live with.... We also want to support the school in things they propose and we agree with. In addition, we want to involve the parents of the school in the sense that we stimulate them to come to school, to take part in things we organize and look ... for example, if you help the children to read in the classroom, you can see what happens.... Or simply doing things together with other parents. Getting to know each other. And communicating points of discussion to the school (Chairwoman of the parents' association).

Most of the members of the parents' association are well-educated and articulate. Only one immigrant mother belongs to the association. Underprivileged parents, although well represented in the school, do not take part in the parents' association. In fact, the association is not at all a reflection of the school's population. In fact, it is an elite organisation that elects and screens its members. The association meets every six weeks in the house of one of the members. The school head and teachers are not all positive about the parents' association and often feel that the activities of the association interfere with their business. Actually, in the Triangle there is a manifest conflict between the parents' association and in the first place - the school head and the assistant director. According to micropolitical theory, conflicts are constantly apt to occur in all organisations. Schools are 'arena's of struggle' that are torn by actual and potential conflicts between the members (Ball 1986). Most of the time, communication and interaction in schools happen routinely but conflict is always possible. Conflicts stay below the surface until something happens that makes them explode. We will discuss the situation in the Triangle in more detail.

For a long time, the conflict between the school head and the parents' association was implicit and did not surface. There were three things that brought it into the open. First, a new school head was appointed, and this new school head, Frieda, had clear ideas about what parents should and should not do in the school. Second, during the first meeting of the parents' association this school year (2004-2005), the 
association criticized some incidents in school. According to both Frieda and Annie, these criticisms were undeserved. Frieda discussed this with the chairwoman of the association, and they decided to arrange a new meeting of the association at the school where clear arrangements about the do's and the don'ts of the parents' association would be made. However, before this meeting took place, the parent's association decided they wanted to establish a new parents' council as permitted by the new participation law. At first, Frieda and Annie opposed this new parents' council as they did not want the parents to interfere with the school policy. However, to establish a parents' council, the parents' association needed signatures of $10 \%$ of the parents of the school, for which they organised a petition. This was the third factor that led to the outburst of the conflict. The grounds of this conflict were precisely the negotiation about the invisible line, we described above. According to Annie and Frieda, the line that separated the domain of the parents, more specifically the rights of the parents' association, from that of the teachers/school head had been breached. The objectives of the parents' association and according to which they acted were not compatible with what both school heads (the former and the present) considered to be the task of the parents' association. According to Annie and Frieda, the main task of the association was to support the school. The parents' association was useful because they brought in money through the events they organised. They did not want the parents' association to 'interfere in the school's business':

Respondent: I don't really believe in throwing the schools open to parents. No. I never did. Interviewer: There has to be a distance?

Respondent: I do think so, yes. I feel that when I go to the meetings of the parents' association. The first time I went, it really felt like a slap in my face. They are gathered there, arranging all sorts of things like the quiz and the fancy fair and this and that but they are also interfering in the life of the school and that's what I don't like (Annie, school head).

What Annie considered 'interfering in the life of the school' becomes clear in the following comment:

Yes, the previous time [at a meeting of the parents' association], we had that very difficult case of Bashir whom we had to take in but who is unmanageable. He does not fit in here. But to get rid 
of him, a whole procedure is needed. It really is a very difficult case and he made that classroom, a difficult group, hell. I agree that those people [from the parents' association] care but the next meeting, Bashir was an item on the agenda. And then I have to weigh my words and say: 'Yes, we are working on that but I can't say anything about it because it's pending. We do our best but we can't do any more.' And then they say: 'Yes, but why did you take him in?' I say: 'Because I have to, I can't refuse him'. In fact they don't know enough about those things. And then they ask: 'Whom do we have to call then? Do we have to call the Minister to get him away here?' Things like that ...really interfering actually. 'And what about X?' 'And is that problem solved yet'? (Annie, school head).

Because the parents' association also supports and helps the school, Annie does not want to challenge them. She finds it difficult to tell the members directly that she thinks they go too far. Because of the school's interest, Annie thinks that it is best to handle this diplomatically. Her micro-political strategy is to remain silent. The new school head, Frieda, told the chairwoman of the parents' association that she did not agree with the way the association criticized the school. This contradiction between the objectives of the parents' association and those of the school team under the influence of the new school head resulted in overt conflict. The line that separated the parents' domain and the school's domain had never been clarified. In the Triangle, the line was there but only implicitly and invisibly, and the members of the parents' association unknowingly crossed it:

So I had a conversation with her (Frieda) and I said we would talk about it during the next meeting. And that we would draw clear lines. Until last year, there weren't such lines you could not cross as a matter of speech. And now, for her, we crossed a line we did not know existed. As simple as that (Chairwoman of the parents' association).

To justify why parents should keep their distance, Annie and Frieda cited the teacher's professional status. Parents should not interfere in educational matters because they are not qualified to do so. And this applied not only to the parents of the parents' association but to all parents. Many of the teachers in the 
Triangle shared the same opinion. They wanted to maintain their professional autonomy and thought it is difficult to do so if parents interfere too much. There is a clear contradiction between the opinion of the school head and the teachers that the school is a professional organisation that accepts only professional rules and the opinion of the parents, who want to take care of their children and, while not being opposed to professionalism, want some authority. Most of the teachers had the same opinion about the functioning of the parents' association as have Annie and Frieda:

I think there should be a parents' association. And I think parents should know what's happening in school. But I think the right to decide is still in our hands. They may know what happens, they may be informed. They may express their opinion, but in the end we are the ones who decide what needs to be done (Teacher: female, 37 years old).

For the teachers, the parents' association is not part of the school organisation. In their opinion, the parents do not belong to the school, in spite of their legal rights.

In general, we see that both school heads (the former and the present one) and the teachers of the Triangle were rather suspicious of parents. The struggle between the parents and the teachers is obviously present here. The teachers of the Triangle sometimes feel vulnerable with respect to the parents and want to keep them outside their classroom:

Interviewer: Do you think schools should stimulate parents to become more involved?

Respondent: I don't like seeing them in the school, let me put it this way.

Interviewer: And as a reading helper?

Respondent: That they can do, for all I care.

Interviewer: But rather not?

Respondent: Rather not, that's right. I can do without someone looking over my shoulder'.

(Teacher: female, 44 years old) 
Taking all this information into consideration, we can characterize the Triangle as a 'dissension school'. Elements of conflict dominate the relation between the school teachers and school head and the parents. The 'arena of struggle' (Ball 1986) is clearly present in this school. There was an open struggle between the present and former school heads and the members of the parents' association. The parents' association operates as a true 'interest set' (Hoyle 1986), which takes action to defend the parent's interests. Micropolitics are clearly active in this school. At stake are the different views of the school head and the parents about the function of the parents' association. Because the parents' association is an elite organisation whose members have many resources to put into the battle, uncertainty and vulnerability are generated on the part of the school head and the teachers. The power balance in this school clearly leans towards the parents' association. The teachers and the school head often felt threatened by the parents.

In general, however, the parents of the Triangle did not have negative feelings about the school. Most of the parents felt welcome in the school, liked to come to the school, and were positive about the contacts with the teachers. However, a few parents - members of the parents' association - talked about a 'barrier' between the teachers and the parents:

There also is a clear barrier between parents and teachers. But I think that is necessary. Otherwise, these people can't do their job properly. So, there is a kind of distance but I think that's necessary (Father: social worker, member of the parents' association).

In general, however, we found that the school initiated the conflict, not the parents. The school had to deal with a lot of insecurity. First, the many changes of school head created a lack of continuity in school, and, second, the population of the school was changing. While before, the school population was upper middle-class, in recent years more and more lower-status and immigrant children enrolled. Not all of the teachers adjusted easily to this new population. Third, during the school year 2002-2003, the school had been screened by the inspectorate, and the report was negative. It was not until the present school year (2004-2005) that the school was finally approved.

In this climate of insecurity, the new participation law caused a great deal of controversy. Actually, the introduction of this law, in particular the establishment of the school council, was an immediate cause 
of the conflict between the parents' association and the former and present school heads. While the school heads and the school governing body in the Triangle followed the umbrella-organization of the Catholic schools in their objections to the law, the parents' association decided on their own they wanted to install a parents' council. The main reason of this was they wanted more power in school matters:

I think the parents' council can have more a counselling function in the school council. That there will be a bit more regulation between us. While the parents' association often is more involved in practical things. Although we try to avoid that. We try to do more than just organise parties ... if there are questions... we try to talk about certain matters. But eventually, the school, the school head does what she decides with the things we bring in. Even though we are saying - as a matter of speaking - for years now that the school excursions are expensive, they stay expensive.... But with the new decree that will be regulated differently and that's why we want to figure that out' (Chairwoman, parents' association).

The members of the parents' association organised a petition. Both of the headmasters, Frieda and Annie, were not in favour of the parents' council. They thought the parents would interfere more and more in the school's business and were convinced that most of the parents were not at all interested in such things, so it would be a small elite group of parents that would make all the decisions. The school head, who was accustomed to an old-fashioned, amateurish approach to the parents' association, had to learn to live with more mature parents of the parents' association who wanted to use the law to gain power and were neither supported nor hindered by other parents. This caused conflict. The structural context of this conflict was the VSKO's opposition to the decree. The negotiation context was formed by the actions of the parents' association, the organisation of the petition, the interactions they had with the head, and the power balance between the parties.

Because the necessary $10 \%$ were gathered, the establishment of the council could not be prevented. In January 2005, the parents' council was installed. The council consists of 12 parents - mostly members of the former parents' association - and a new chairman. From these 12 parents, three were chosen to represent the parents in the school council. The school council will be active as of April 2005. 
According to the new chairman of the parents' council, the tensions between Frieda and the members of the parents' association are gradually decreasing. He thinks that Frieda's resistance was caused by insecurity because she was new to the school:

She was pretty insecure towards the parents and the involvement of parents and that's why there were some communication problems in the beginning. But I understand that it's difficult if you're coming to a new school, I think that's the background idea of her reserve.... And now it appears we are gradually getting along better.

Interviewer: Has the relationship improved compared to the beginning of the school year? Respondent: I do think so. Yes. For me at least. I experience a more positive attitude towards the parents' council. But in the beginning, it was difficult. She clearly showed that she wasn't happy with the way we handled things (Chairman of the parents' council, former member of the parents' association).

Now that the parents' council is functioning, the resistance of the school head is decreasing. It is too early to draw far-reaching conclusions but it looks like the battle in the Triangle is slowly fading away.

\section{The Rainbow School}

The Rainbow school is a grant-aided official school, i.e., the organizing body of this school is the city council. The school has about 190 pupils and so is a small school. It is located in a poor district of the city. The playground is alongside a quiet street. One enters the school through a side building where the head's office and the teachers' room are. The classrooms are situated at the other side of the playground. The Rainbow recruits only from families living in the immediate vicinity of the school. Almost half of the pupils are immigrants, mostly Moroccans and Turks. The socio-economic status of the parent population is rather low. Most of the parents are labourers, but almost $20 \%$ of the parents are unemployed. A substantial number of the Belgian pupils are underprivileged. The school head, Lieve Jochems, has been directing the school since the 2002-2003 school year. Before she became school head there, the school 
population had been declining because the school had in a short period of time a number of school heads (three in one school year), which led to inconsistency in the school policy. The parents' association was very unhappy with this and organised a petition amongst all the parents to rescue the school. One of the things they demanded from the organizing body was a new school head who would stay at least five years. This new school head was Lieve Jochems, a young, dynamic woman who stimulated innovation. The Rainbow's parents' association consisted of 10 to 15 members and met more or less every six weeks. All of the parents of the school were invited to every meeting. The chairman of the association, Jef Willems, a sculptor and an active member of a small Marxist political party, had an important role in the parents' association. As from September 2001, he was the prime motivator of the parents' association. Before that, the only function of the parents' association was to raise money. Jef set up a new association whose task was, besides the organizing of activities to raise money, to make an intrinsic contribution to the school's policy. One of the first actions of the parents' association under his chairmanship was the petition and the accompanying demand of a new school head. We can call the parents' association of the Rainbow an action group.

Contrary to what had happened at the Triangle School, the actions of the parents' association at Rainbow School were welcomed and approved of by the school staff. The relationship between the parents' association and the school head was characterized by cooperation. They supported each other in their actions to increase parental involvement in the school. The school head, Lieve Jochems, realized that, if she wanted to improve the school, she would have to get the parents' association on her side. One of the first things she tried to do after arriving at the school was to open up the school to the parents:

I became school head last year and the school was in trouble. The first thing I said was: We have to be much more open towards the parents'. Before, the school was a closed circle. Everything was kept inside and that's not healthy (Lieve, school head).

An important micro-political strategy of the school head was thus to involve the parents in general and the parents' association in particular in the school. She did that primarily by being open to the parents. The parents' association is kept informed about all the school matters: 
Everything is open for discussion. I try to keep no secrets from them [the members of the parents' association]. Right now, for example, we have a financial problem because one of the school heads before me bought a very expensive Xerox machine.... And they [the members of the parents' association] are helping to find solutions (Lieve, school head).

Unlike what we saw at the Triangle, this school head was even willing to discuss educational matters with the members of the parents' association:

The parents' association already existed [before Lieve was appointed school head] but they said that if they wanted to say something, the ready response was 'that's educational, that's not your business'. And I did say clearly at the outset: 'Look, there are educational matters you can't touch but that doesn't mean we can't talk about it' (Lieve, school head).

We see that the parents' domain here is larger than in the Triangle. The Rainbow's parents' association is involved in decisions about financial as well as about educational matters. The school head often asks the parents' association for advice:

For example now, Lieve received the proposal to take in a second nursery school. That is something only she can decide. We have nothing to say about that. But she tells us. She asks our opinion and she says 'I think it's important to know I've got you behind me' (Mother: counsellor, member of the parents' association).

As in the Triangle, this parents' association wanted to be more than an organizing committee. What is different from the Triangle is that the objectives of the parents' association are supported by the school head. The parents' association and the school head have the same opinion about what the role of parents in school can be. Instead of conflict between them, we see that the parents and the school head fight together: 
For example when free swimming was abolished, she [Lieve] informed us immediately and she said: 'I think it's important that you, as parents, take action'. So actually she almost encouraged us to fight' (Mother: counsellor, member of the parents' association).

It is not only the relationship between the school and the parents' association that is characterized by partnership. In the contact with parents who are not members of the parents' association, we also find elements of partnership. Initiatives such as the establishment of a mothers' group where mostly immigrant mothers have the chance to talk about school-related subjects, cooperation with community-work organizations, and the installation of a parents' room where parents can sit together during school hours show that this school encourages parental involvement. Unlike the administration of the Triangle, Lieve sees only advantages in parental participation. She does not seem to feel threatened by the parents and or to fear interference by the parents in her professional domain. The teachers of the Rainbow share more or less the same opinion with their school head:

I think this [more parental involvement in school] is a very positive thing. This is very important. Yes. I also think it is enriching for me as a teacher because you look at things from another perspective. Otherwise you always look through the teacher's eyes and now you learn to ... anyway, I think the school can only improve that way' (Teacher: female, 47 years old).

Unlike their colleagues of the Triangle, the Rainbow's teachers do not cite their professional status to keep parents at a distance. This does not mean that all of the Rainbow teachers have better contact with parents than do the Triangle teachers. The teachers' own personal opinions and personality matter, and teachers feel threatened in all kind of schools. However, in general, the Triangle's teachers are more suspicious of parents than are the Rainbow's teachers. In sum, the most common strategy of parents, teachers, and administration at the Rainbow School was cooperation. Overall, the parents here had a positive attitude towards the school, we saw no elements of a conflict, and so we can call the Rainbow a 'consensus school'. The different actors saw each other as partners. However, to reach this 
'negotiated order', the members of the parents' association had struggled in the past. The parents' association, stimulated by the chairman, put all their resources into the battle to defend the school's interests. At that time, the survival and stability of the school were at stake. The actions of the parents' association created conflicts with the school head at the time and the organizing body. Peace and partnership between the actors has been achieved only recently. Thus, in the Rainbow; too, there was an 'arena of struggle' (Ball 1986). It is a good example of how conflicts in an organization can be seen as a process through which the organization grows and develops. After the reorganization of the Rainbow and the appointment of a new school head, the battle quieted down and peace returned.

At the Rainbow School, the new participation law has yet to have much effect. The members of the parents' association as well as the school head were happy with the way parents were involved in school and did not see any reason to change it:

Well, actually I think our parents' association already works as a parents' council. The parents already participate in our school. The parents' association as well as the mothers' group are informed about the school policy. So, whatever name we give it, that doesn't matter for us but the way of working is there' (Lieve, school head).

All the parents of the school received a letter about the new decree, but the school head did not receive any requests from parents to establish the parents' council. The school heads of all the schools of the organizing body decided together to establish school councils at the level of the school community. For the Rainbow, this means that there will be one school council together with 11 other primary schools. Each school can nominate a maximum of two teachers and parents to represent the school in the school council. At the Rainbow, two members of the parents' association and one teacher volunteered to represent the school. From all the candidates of the parents and the teachers in the school community, three parents and teachers will be elected for the school council. This means that not all of the schools will have representatives in the school council. When this paper was written (March - April 2005), the elections had not yet taken place, and the school council had not yet been installed. Thus, it is too early to draw any conclusions about the working of the school council. However, for the present, the new 
participation law has not given rise to many changes at the Rainbow. Cooperation and partnership is possible because the issue in the Rainbow is not the legal representation but the openness of the head to the expectations of the parents. In contrast with the Triangle, the goals of the parents' association are similar to what the head wants to achieve. The parents, teachers, and school head are cooperating to improve the school. Moreover, the parents and the school head are on an equal footing as regards their respective positions in the balance of power.

\section{Saint George's School and Comenius School}

The Triangle and the Rainbow are at opposite poles of the dissension-consensus continuum. The two other cases of our study, Saint George's and Comenius, can be situated somewhere between them. Although these two schools differ in many ways from each other, they have one similarity that is important for our typification and is the reason why we discuss them together. Indeed, in both Saint George's and Comenius, we did not find many elements of conflicts in the relationship between the parents and the school. We could say that both schools were characterized by consensus. But, unlike the Rainbow, there was no participation of parents in educational or policy matters at neither Saint George's nor Comenius. Therefore, both schools were characterized by a 'domain-specific partnership', as it were, between the parents and the school. How this domain-specific partnership took shape differently in the two schools will be outlined below.

Saint George's with 230 pupils is a small grant-aided free school. The school is situated in a quiet district of the city in a side-street. The buildings of the school are part of a parochial complex. Saint George's school population is mainly white working and middle-class. Very few immigrant children actually only the children of one Turkish family - attend the school because almost no immigrant families live in this part of town. The school keeps no data on the professions of the parents. According to the school head, who is 55 years old and has been the head for 20 years, the school contains no more than three underprivileged families. Although Saint George's is a small school, the parents' association is large (about 25 members) and very active. The parents' association of Saint George's is responsible for the organization of a number of activities. The main task of the parents' association is to obtain funds for the 
school. Consequently, most of the interactions between members of the parents' association and the school head or teachers concern the practical organization of activities. In general, all the parties communicate well with each other. Disputes are exceptional and if they occur, they are about practical matters.

Unlike the parents' association of the Triangle and the Rainbow, this parents' association does not want to be involved in policy matters of the school. The parents' association wants to be merely an organizing committee and feels no need to participate in decision-making about the school policy. Thus, unlike in the Triangle, the school head and teachers here have no reason to be wary of parents entering their domain. Furthermore, this parents' association is actually a circle of friends. They meet on weekends for drinks, go camping together, and have informal contacts with some of the teachers and the school head. In general, the school culture is open towards parents. However, some of the teachers think parents should not get too much involved in school. Thus, we do find attitudes that might give rise to conflict in the way some of the teachers think of parents. Because of this and because there only is a partnership between the parents and the school in the practical and informal sphere, we can speak of a 'domainspecific partnership'.

With about 400 pupils, the Comenius School is the largest of the four schools. A grant-aided free school founded by a religious Catholic order, it is associated with a secondary school. The secondary and the elementary schools are housed in the same building complex. There are two school heads but only one teachers' room and one parents' association. The school is situated on the outskirts of the city in rather quiet surroundings. Officially, the elementary school is called the 'preparatory division'. The primary intention of the elementary school is thus to prepare the pupils for the secondary school. Over the last 10 years, the school population has evolved from mainly upper middle class to mainly middle class. Although the school is situated in an area where many immigrants live, the proportion of immigrant pupils in the school is small. In part, this is because these pupils often drop out. On average, about $20 \%$ of the pupils are of immigrant origin. In the first three grades of elementary school, this percentage is some $30 \%$, but in the last three forms only about $10 \%$ of the pupils are of immigrant origin. The majority of the parents of Comenius pupils are white-collar workers and professionals. Only $2 \%$ of the parents are unemployed. More or less half of the pupils live within five kilometres of the school. The other half live in the 
surrounding areas. Their parents work in the city, and the location of the school makes it easy for them to drop their children off and pick them up. Furthermore, the traditional reputation of the school influences the parents' school choice. Teachers as well as parents stress that the school makes high demands on the pupils. Comenius is a difficult school where pupils must work hard, and the school attracts intellectually strong pupils. The parents' association of Comenius is not prominent in the school. Relative to the size of the school, the parents' association (10 members) is very small and, compared to the other three schools, organises very few activities. This parent's association has almost no other function than the legal representation of parents in the school. Except for parents' evenings, there are few contacts between the parents and the school in the Comenius School. That the parents' association has no important function fits in the school culture. The teachers, as well as the non-member parents, know little about the parents' association. Moreover, the parents' association has no say in school matters. Discussions rarely occur. The parents' association usually concurs with the school head. The school head of the Comenius school, who is 55 years old and has been the head for 14 years, clearly has a powerful position, and the parents' association supports him. The school head and the parents' association are partners, but the balance of power is on the side of the school head. He assumes that parents, and certainly the parents in the parents' association, are on the same wavelength as he is:

Parents who enrol their child in this school, receive a school brochure with the regulations. They have an intake conversation and if they are, for any reason, not happy with the way things are in school, they go to another school. They don't come to your school and say: 'now, we are going to change all this'. They choose your school with your view. They choose your project and not another project... So parents are in any case people you can assume to be on the same wavelength as you are. They can have other ideas about certain things, but mainly they follow you. And that is especially true for the parents of the parents' association because they are people who want to invest energy in the school. Because, eventually, it is an effort, don't you think? (School head). 
The distance between the parents and the school head/teachers in the Comenius School is much greater than in the other three schools. The Comenius teachers seldom involve parents in their classrooms, for example. Most teachers want to preserve control over their own classroom and do not want much contact with parents. They do not want interference from parents. The parents themselves do not feel the need to participate in school life. They know the school is not very communicative and open towards parents, but most of the parents have no problem with that:

We always said: 'raising the children is our task and the school has to be an extension of this'. So we chose a school of which we thought they had an educational project we could approve of in general, a school we thought was a good school (Mother, white-collar employee).

As at Saint George's School, we can characterize the relation between the parents and the school at Comenius as a 'domain-specific partnership'. First, there is little contact between the parents and the teachers and the school head at Comenius. Moreover, the interactions that take place are generally formal and detached. The teachers consciously keep the parents at a distance. Therefore, we cannot speak of a genuine partnership. However, there is also no real dissension at Comenius. There is no conflict between the parents and the teachers or the school head. The parents' association strongly supports the school head. Fundamental criticism or disputes are uncommon.

At Saint George's as well as at Comenius the new participatory law did not change the relations in the school. Neither school heads see few advantages in the new regulations and support the criticism of the VSKO, the umbrella organization of the Catholic schools.

At both schools, the parents' association was transformed into a parents' council. However, according to the school heads and the chairmen of the parents' association, this will only involve a change of name and will not bring about any fundamental changes in operation. At Comenius, as well as at Saint George's, both the parents and the school heads are pleased with the way the parents' association and parental participation functions and see no reason to change it. At Comenius, all of the parents received a letter with information about the decree and an invitation to ask for the establishment of a parents' 
council. The school head received no reactions to this letter. At Saint George's, the parents' association invited someone to one of their meetings to inform them about the decree and then transformed themselves into a parents' council. Next school year, all parents will receive an invitation to become a member of the parents' council. At Saint George's, the representatives of the parents in the participation council will become the representatives on the school council. At Comenius, the representatives for the school council had not yet been chosen at the time of this writing.

Both at Saint George's and at Comenius, the parents are not willing to have a say in school matters. Conflicts and struggle in organisations are generally caused by discussions about all aspects of decision-making (Bacharach \& Mitchell 1987: 410). This means that when parents are indifferent about decision-making in the school, tensions or conflicts rarely occur. The 'negotiated order' (Strauss 1978; Ball 1986: 20; Bacharach \& Mundell 1993: 424) between the different parties at both schools is rather stable, even though we cannot speak of a genuine partnership because there only is cooperation in practical/organisational or informal areas.

\section{Summary}

In the following table we summarize the main findings of the cases described above. We focus here on the relationship between the parents' association and the school head. In the following section we will go into possible explanations of the research findings.

[Insert table 2 about here]

\section{Discussion}

In each school, the invisible line that separates the school's domain and the parents' domain has been negotiated differently. The four schools differ significantly in how they deal with parents, and the objectives of the parents' associations vary from money-raising activities to participation in the formulation of school policy. Depending on what the members of the parents' association want to achieve, the parents' association triggers different reactions from the school heads and the teachers. The 
daily interactions and relations inside the school determine the shape of the parental involvement. In each school, the power balance of the parents' association, the school head, the teachers, and the organizing body differs and can change according to the circumstances. Obviously, 'the various structural conditions of the settings affect the actions of the negotiating parties, the aims they pursue through negotiation and alternative modes of action, their tactics during the negotiations, and undoubtedly the outcomes of the negotiations themselves' (Strauss 1978: 235). Hence, it is not easy to formulate a legislative framework of parental participation that fits every school. The participation law of the 2 April 2004 is clearly intended to increase the participation of parents in schools. The purpose of this law is thus to move school cultures towards more participation. This implies the functionalistic conviction that change imposed from above is possible. Implicitly, this conviction assumes that an organization is a technical mechanism peopled by malleable actors and totally rejects the micropolitical perspective. Starting from micropolitics, an organization can change only if the active interpretative responses of the actors in the organization are taken into consideration. Indeed, there is a big difference between changes of policy and changes of practice. The 'arena of debate' must not be confused with the 'arena of implementation' (Ball 1986: 39). That the government wants to encourage parental participation does not mean that participation will actually increase. Therefore, the actors in the organization must engage in a process of negotiation.

For the time being, only at the Triangle has the participation decree led to any real changes. The Triangle is the only school where the parents demanded the establishment of a parents' council. Although Saint George's and Comenius also established a parents' council, it is only at the Triangle that the parents' council seems to have different objectives than the parents' association. Moreover, only at the Triangle did the parents' council attract new parents who were not yet members of the parents' association. The relations between the different parties did not change as a result of the implementation of the new participation decree. Where there is partnership, the actors stay partners. Where there is struggle, the struggle intensifies. Change or the possibility of change can bring underlying conflicts and differences of opinion to the surface. Moreover, change is to be expected in organizations where the social system is fragmented by different values and interest groups (Baldridge in Ball 1986: 28) as is the case at the Triangle School. However, it is still too soon to predict the long-term consequences of the establishment of the new council at the Triangle. 
The question now is how we can explain the differences in these cases. We will briefly discuss some of the main factors that are responsible for this variation. To begin with, the school head is of primary importance in this respect. The school head determines to a great extent the school's functioning, and his or her role is central for understanding the micropolitics of the school. Moreover, the school head influences the actions of the teachers. Teachers seem to develop patterns of social interaction in direct response to the school head's leadership (Blase and Anderson 1995). In the interactions of teachers with parents, the support teachers receive from the school head is important. Our research results show the importance of the school head in the relationship between the parents and the school. We see that stable and secure leaders who share their power form a partnership with parents and so move to creating more effective schools. In two of the four schools, a new school head had just recently been appointed, and the impact on the school's functioning was clear. In the Rainbow School, the school head managed to improve the relations with parents, who had previously been kept on a distance. She improved the relations with the parents' association and succeeded in creating an open school climate. By encouraging parental involvement, she also improved the relationship between the parents and the teachers. Here we find a true parent-school partnership school, and that was mainly due to the school head's efforts. In the Triangle School, the appointment of the new school head had the opposite effect. Instead of improving the relations with the parents, which had not been very good, her arrival intensified the tensions. Because she was insecure, coming to a new school, she felt threatened by the criticism of assertive members of the parents' association. Moreover, her view of the responsibilities of the parents' association in the school clashed with the objectives of the parents' association and the school council. The result was dissension between the parents and the school. The school heads of Saint George's and the Comenius School resemble each other. Both were 55-year-old men who had been leading their schools for many years. They both had clear ideas about the effective functioning of their school, and in both schools the relationship between the parents and the school were smooth with few areas of conflict.

In view of the teachers' attitude toward parents, the idea of the 'teacher as a professional' (Aelterman et al. 2002b) is obviously still alive among contemporary Flemish teachers. Several teachers refer to their 'professional expertise' to justify why they wanted to keep parents at a distance. While there are obviously intramural differences between teachers in their attitude towards parents, patterns between 
the schools also emerged. We characterized the Triangle School as a 'dissension school'. Several teachers of this school referred to their professionalism while discussing their contacts with parents. Not all of the teachers had a negative attitude towards parents, but in the Triangle school there was an atmosphere, especially among the older teachers, of 'keeping parents at a distance'. The teachers at the Triangle School were suspicious of parents, whom they felt frequently threatened their professional autonomy. In the Rainbow School, we did not find any of this happening. None of the teachers there mentioned their professional expertise with respect to their relationship with the parents. The parents at the Rainbow School were intensely involved in school, but the teachers had no problems with it. They did not feel threatened. Again, Saint George's and the Comenius School were situated somewhere in between. In the Comenius School, the teachers worked most of the time individually in their own classrooms, and there was a 'professional mentality' among them more than in the other schools. The teachers there were convinced of their own professional expertise and did not want any interference. Nevertheless, compared to the Triangle's Teachers, the teachers of Comenius felt less vulnerable in their relationship with parents because they had less contact with the parents. The distance was larger, the parents had fewer complaints, and, consequently, the teachers had less reason to feel threatened. In Saint George's School, a few of the teachers referred to their professionalism in the context of their relationship parents. The notion of the 'expert teacher' was alive there but less explicitly so than at Comenius and the Triangle.

Of course, the parents themselves are important actors in the relationship between them and the school. The social background of parents is the main explanatory factor that accounts for the differentiation in parental involvement. Research (for example, Lareau 1989, Crozier 2000, Reay 1998) shows that middle-class parents have a different attitude toward the school than do working-class parents. Middle-class parents are more visible in the school, are more apt to interfere, and are more self-confident in their relations with teachers than working-class parents. Although this paper has not focussed primarily on differences in parents' socio-economic status, the data show some aspects of inequality in parent participation. If we look at the composition of the four parents' associations, we see a predominance of middle-class parents. Even in schools where the school population in general has a low socio-economic status, mainly middle-class parents take part in the parents' association. In all four of the schools, the average educational qualification of the members of the parents' association was higher than the average 
educational qualification of the parents in general, although the difference varied from school to school. In the Triangle, the difference was most explicit. While the average social status of the Triangle's school population was rather low, the members of the parents' association were for the most part well-educated, assertive people with quite adequate verbal skills. For example, in the discussion about the implementation of the participation law and the establishment of the parents' council, these parents showed they were better informed than the school head and the teachers. The parents had succeeded in becoming experts in educational matters, and they made the school staff feel threatened, which led to the struggle. In the Comenius School, the socio-economic status of the members of the parents' association was also higher than the average in the school, although the difference was less explicit because the social status of Comenius' parents on average was rather high. However, some parents were put off by this social threshold and saw the parents' association as an 'elite group'.

Our data show that the parents' associations of the four schools as well as the present or future parents' councils are controlled mainly by middle-class parents. Whatever the average social status of the school population as a whole, we see that mainly white, middle-class parents who are well-educated, wellinformed, and articulate become involved in parents' associations. Unlike Vincent and Martin (2000) in their study of two secondary school discussion-based parents' forums, we cannot directly relate the socioeconomic status and respective resources of the parents' association's members to the association's functioning, goals, and motives. Vincent and Martin found clear differences between the forum of Willow, consisting mostly of higher-educated, public-sector 'caring' professionals, and Carson, where the members in general have experienced some success in income and occupational terms, despite a relative lack of success in educational terms' (see also: Vincent 2001). Both groups are considered to be 'elite groups' (Vincent and Martin 2000: 475), as in our research. Although the Carson forum operates only in the limited realm of fundraising, rarely engaging in wider issues, the Carson forum parents did not feel as confident and at ease as the Willow forum parents in forum meetings and did not want to discuss educational matters as these were the professional's domain. Willow forum parents 'did not trust the school to the same degree. They concluded the stakes where too high to allow the handing over of their child's education to the school, without maintaining sustained involvement on their part' (Vincent and Martin 2000: 473). 'These contrasting reactions are analysed in terms of 'the parents' differing resources, 
attitudes and assumptions which they brought to their relationship with schools' (Vincent and Martin 2000: 475).

The results of our research are not straightforward in this respect. In the Rainbow School and the Triangle School, we found that the parents' association discussed academic and school-policy matters.

Both parents' associations were self-confident in their relationship to the school head and the teachers. At Comenius and Saint George's, the goals of the parents' associations were limited to fund-raising and social activities. Although all four associations were led by middle-class parents, the Comenius parents exceeded the other parents in their average amount of cultural resources. However, the Comenius parents' association was the least active one, and the members seemed to be the least involved in school matters. They put their trust in the professionals' hands more than did the parents in the other schools. These results somehow run counter to what might be expected but can be explained by Lareau's (1989) idea that cultural resources need to be activated to be effective. It is not sufficient to have the resources. They need to be activated by actors, through their decisions and actions. Different factors influence these decisions and the actions of individuals. The Comenius' parents in general have ample resources but are also busy deploying them in their professional careers. These parents have less time to be involved in school life and often do not live nearby. School size also matters. Comenius is a large school where the contacts between the parents and the teachers/school head are often impersonal. Moreover, the traditional school culture did not allow much parental interference. The ethnicity of parents was not examined as an explanatory factor. Only native Belgian parents were interviewed. Moreover, our data do not allow us to draw conclusions about gender differences. Our results point in the direction that both men and women are members of the parents' associations and can play leading roles in the association's functioning.

\section{Conclusion}

Only when the school organization is studied at first hand and in process, ethnographically, can elements of partnership and conflict be detected. Inter- and intraschool differences over time emerge. Most often, micropolitical actions occur unconsciously and pass by unnoticed and are usually experienced as part of the daily routine in the school. However, we have shown that the attentive researcher may find 
moments and elements of conflict at certain moments in seemingly peaceful surroundings. The patterns of interaction between the parents (of the parents' association) and the school that we found were dissension, genuine partnership, and domain-specific partnership. Although micropolitical theory defines the school as an 'arena of struggle' (Ball 1986), this does not mean that conflict is the most common pattern of interaction at school. On the contrary, in two of the four schools we found a stable environment with neither full partnership nor parent-school conflicts. In schools that have experienced and stable leaders and where everything is going smoothly, parents are rather indifferent towards involvement in decision-making.

Different elements influence the structural context in which a parents' association operates. The results show that the socio-economic status of the school population has little influence on the functioning of the parents' association. In each of the four cases, middle-class parents were in charge of the parents' association or the new parents' council. In the Rainbow School, one very committed parent made a big difference. In the Triangle School, a small, elite group of educated, upwardly-mobile parents used their 'voice' and pushed their demands through, which led to feelings of being threatened in the school head and the teachers. These middle-class parents were the people most capable of, and most effective at, challenging 'expert systems' (Giddens 1991). They put pressure on the school staff and, thanks to the new participation law, enforced their own participation in school policy (see BirenbaumCarmelli 1999 for a more far-reaching example of how middle-class parents may exercise power).

Furthermore, we can conclude that only in the schools with a clear presence of underprivileged children does the parents' association bring about changes or is involved in more substantial matters. Only in these schools does the parents' association enhance real 'empowerment' (Vincent 1996: 6) of parents. In the schools serving a public with a higher socio-economic status, the members of the parents' association tend to want to preserve things as they are.

Besides, the results show that conflict depends not only on a clash of opinions between different actors at the school but also on the experience of the school head, the motivation of the parents' association to take action, and the aims of the parents' association.

Moreover, the implementation of the new participation law in the four schools demonstrates that legislation needs to be interpreted, incorporated, and experienced by the micro-political actors in the 
schools if real changes are to occur. Policymakers cannot enforce changes by simply issuing a new decree unless these actors agree with it, at least to a certain extent. Finally, the paper shows that the school meaning the school head, the teachers, and the parents - needs to invest a great deal of effort if parental participation is to be achieved. Parental involvement has to be worked on.

\section{Notes:}

(1) Belgium is a federal state consisting of Regions (economic) and Communities (cultural). There are three Communities in Belgium: the Flemish, the French-speaking, and the German-speaking. The Communities are responsible for educational policy.

(2) In Belgium in general and in Flanders, schools, which may be owned by different organizing bodies, are grouped in educational networks on the basis of their legal status. There are three networks: the network of the community schools, which are organised by the Flemish Community, the network of provincial and local authority schools, the 'grant-aided official schools', and the network of grant-aided free schools organised by free associations or non-profit organizations (Verhoeven and Dom 2002: 17$18)$.

(3) Mc Neal (2001: 172-173) refers to the following possible causes of the inconsistency in findings linking parent involvement to academic achievement: 1) the use of perception measures by teachers rather than direct reports by students and/or parents; 2) a failure to fully conceptualize parent involvement into its constituent parts including parent-child, parent-parent, and parent-school components; 3) not fully assessing the extent to which parent involvement differently affects academic achievement by social class; and 4) parent involvement has little direct effect on achievement because it is essentially a cognitive outcome and parent involvement predominantly affects behavioral outcomes.

(4) The criterion of school size is calculated by taking tertiles of the total variance in school size of all the primary schools in the city. That way, we distinguish small schools (108-230 pupils), medium-sized schools (231-330 pupils) and large schools (331-640 pupils).

(5) As indicator of the percentage of 'underprivileged children' per school we used the percentage of GOK (Equal Educational Opportunities) - target pupils. A GOK-target pupil is: a pupil in a family that lives on social services or a pupil who is temporarily or permanently being taken care of outside the family by foster parents or by a social service, or a pupil whose parents are gypsies, or a pupil whose mother 
does not have a certificate of secondary education (Decree concerning Equal Educational Opportunities, 2002, art. VI.2, §1).

(6) Only in the Rainbow school is there a mothers' group. Every two weeks, the mothers, who are mostly immigrants, meet to discuss school-related matters. Through this group, the school tries to involve these mothers more in school -life.

(7) Pseudonyms are used for the schools as well as for all the respondents

(8) In 2004-2005, Frieda Van de Walle, former school head of another school in the city, has been leading the school with the support of Annie, who works part-time as assistant director of the school.

\section{Bibliography:}

Aelterman, A., Verhaeghe J.P., Engels, N., Van Petegem, K., Sys, H. and Panagiotou, C. (2002a) Het welbevinden van de leerkracht: de ontwikkeling van een bevragingsinstrument voor het meten van het welbevinden van leerkrachten basis- en secundair onderwijs OBPWO-project 00.06.

Aelterman, A., Verhoeven, J., Rots, I., Buvens, I., Engels, N. and Van Petegem, P. (2002b) Waar staat de leraar in onze samenleving? Een onderzoek naar opvattingen over de professionaliteit en de maatschappelijke waardering van leerkrachten (Ghent: Academia Press).

Bacharach, S.B. and Mundell, B.L. (1993) Organizational politics in schools: micro, macro and logics of action, Education Administration Quarterly.

Bacharach, S.B. and. Mitchell, S.M (1987) The generation of practical theory: schools as political organizations, in J.W. Lorsch (ed.), Handbook of Organizational Behavior (Englewood Cliffs: Prentice Hall), 405-418.

Ball, S.J. (1986) The micro-politics of the school. Towards a theory of school organization (London: Methuen \& Co. Ltd).

Ball, S.J. and Vincent C. (2000) New class relations in education: the strategies of the 'fearful' middle classes, in J. Demaine (ed.), Education Sociology Today (London: Macmillan), 180-195.

Bidwell, C. (1965) The school as a formal organisation, in J. March (ed.), Handbook of organisations. (Chicago: Rand McNally \& Company), 972-1022. 
Bilton, T., Bonnett, K., Jones, P., Skinner, D., Stanworth, M. and Webster, A. (1996) Introductory Sociology (New York: Palgrave).

Birenbaum-Carmeli, D. (1999) Parents who get what they want: on empowerment of the powerful, Sociological Review.

Blase, J. (1987) The politics of teaching: the teacher-parent relationship and the dynamics of diplomacy, Journal of Teacher Education.

Blase, J. (1991) The politics of life in schools. Power, conflict and cooperation (Thousand Oaks: Corwin Press Inc).

Blase, J. and Anderson, G. (1995) The micropolitics of educational leadership: from control to empowerment (London: Cassel).

Brown, P. (1990) The 'third wave': education and the ideology of parentocracy, British Journal of Sociology of Education.

Calgren, I. (1999) Professionalism and teachers as designers, Journal of Curriculum Studies.

Chen, H. (2003) School-based management: the micropolitical interactions among the headteacher, directors, teachers and parents. Paper presented at the British Educational Research Association Annual Conference, Heriot-Watt University, Edinburgh, 11-13 September.

Crozier, G. (2000) Schools and parents: partners or protagonists (Staffordshire: Trentam Books Limited).

Deem, R. (1994) Free marketeers or good citizens? Educational policy and lay participation in the administration of schools, British Journal of Educational Studies.

Densmore, K. (1987) Professionalism, proletarianization and teacher work, in T. Popkewits (ed.), Critical studies in teacher education. Its folklore, theory and practice (London: the Falmer Press), 130160.

Desimone, L. (1999) Linking parent involvement with student achievements: do race and income matter? Journal of Educational Research.

Fehrmann, P., Keith, T. and Reimers, T. (1987) Home influences on school learning: direct and indirect effects of parental involvement on high school grades, Journal of Educational Research.

Feuerstein, A. (2000) School characteristics and parent involvement: influences on participation in children's schools, Journal of Educational Research. 
Flanders (Belgium) Parliament, 1991, Decreet betreffende de medezeggenschap in het gesubsidiëerd onderwijs van 23 oktober 1991, Belgisch Staatsblad, 14 November 1991.

Flanders (Belgium) Parliament, 2004, Decreet betreffende participatie op school en de Vlaamse Onderwijsraad van 2 april 2004, Belgisch Staatsblad, 6 August 2004.

Giddens, A. (1991) Modernity and Self-Identity (Cambridge: Polity Press).

Goldring, E. and Hausman C. (1999) Reasons for parental choice of urban schools, Journal of Education Policy.

Goldring, E.B. and Shapira, R. (1996) Principal's survival with parental involvement, School effectiveness and school improvement.

Griffith, J. (1996) Relation of parental involvement, empowerment and school traits to student academic performance, Journal of Educational Research.

Green, L. (1968) Parents and teachers. Partners or rivals? (London: George Allen and Unwin LTD).

Hargreaves, A. (2000) Four ages of professionalism and professional learning, Teachers and teaching: History and Practice.

Ho, E.S. and Willms J.D. (1996) Effects of parental involvement on eight-grade achievement. Sociology of Education.

Hoyle, E. (1986) The politics of school management (London: Hodder and Stroughton).

Kelchtermans, G. (1996) Teacher vulnerability: understanding its moral and political roots, Cambridge Journal of Education.

Lareau, A. (1989) Home advantage (Philadelphia: The Falmer Press).

Lareau, A. (1997) Social class differences in family-school relationships: the importance of cultural capital, in A. Halser, H. Lauder, P. Brown and A.S. Wells (eds.), Education, Culture, Economy, Society (Oxford: Oxford University Press), 703-717.

Mahieu, P. (1988) Participatie aan schoolmanagement. Een organisatie-sociologische benadering (Antwerp: UIA. Departement politieke en sociale wetenschappen).

McNeal, R. (2001) Differential effects of parental involvement on cognitive and behavioral outcomes by socio-economic status, Journal of Socio-Economics. 
Ozga, J. and Lawn, M. (1988) Schoolwork: interpreting the labour process of teaching, British Journal of Sociology of Education.

Peña, D. (2000) Parent involvement: influencing factors and implications, Journal of Educational Research.

Reay, D. (1998) Class Work. Mothers' involvement in their children's primary schooling (London: UCL Press Limited).

Sheldon, S. and Epstein, J. (2005) Involvement counts: family and community partnerships and mathematics achievement, Journal of Educational Research.

Stevenson, D. and Baker, D. (1987) The family-school relation and the child's school performance, Child Development.

Strauss, A. (1964) Psychiatric ideologies and institutions (New York: Free Press).

Strauss, A. (1978) Negotiations. Varieties, contexts, processes and social order (San Francisco and London: Jossey-Bass Publishers).

Strauss, A. and Corbin, J. (1991) Basics of qualitative research. Grounded theory. Procedures and techniques (Newbury Park, London, New Delhi: Sage Publications).

Teddlie, C. and Stringfield, S. (1993) Schools do make a difference: Lessons learned from a 10-year study of school effecs (New York: Teachers College Press).

Van Heddegem, I. and Verhoeven, J.C. (1998) Teachers' representatives and their assessment of the new Participatory School Councils in Belgium, Teacher Development.

Van Zanten, A. (2002) Educational change and new cleavages between school heads, teachers and parents: global and local perspectives on the French case, Journal of Education Policy.

Verhoeven, J.C., Devos, G., Stassen, K. and Warmoes, V. (2003) Ouders over Scholen (Antwerp: Garant). Verhoeven, J.C. and Dom, L. (2002) Flemish EURYDICE report 2001: education policy and organisation in Flanders (Brussels: Ministry of the Flemish Community. Department of Education).

Verhoeven, J.C. and Kochuyt, T. (1995) Kansenongelijkheid in het onderwijs. Een biografisch onderzoek naar het schoolgaan in arbeiders- en kansarme gezinnen (Brussel: Federale Diensten voor wetenschappelijke, technische en culturele aangelegenheden). 
Verhoeven, J. C. and Van Heddegem, I. (1999) Parents' representatives in the new participatory school councils in Belgium, Educational Management and Administration.

Vincent, C. (1996) Parents and teachers: power and participation (London: Falmer).

Vincent, C. (2001) Social class and parental agency, Journal of Education Policy.

Vincent, C. and Martin, J. (2000) School-based parents' groups - a politics of voice and representation? Journal of Education Policy.

Vincent, C. and Martin, J. (2002) Class, culture and agency: researching parental voice. Discourse: studies in the cultural politics of education.

Waller, W. (1961) Sociology of teaching (New York: Russel \& Russel).

Weick, E. (1976) Education organizations as loosely coupled systems, Administrative Science Quarterly.

White, K., Taylor, M. and Moss, V. (1992) Does research support claims about the benefits of involving parents in early intervention programs? Review of Educational Research. 
Table 1. Formal participation of parents in Flemish primary education.

\begin{tabular}{|l|l|l|l|l|}
\hline Period & Name & Educational network & Members & $\begin{array}{l}\text { Voluntary or } \\
\text { mandatory }\end{array}$ \\
\hline pre-2004 & school council & community network & $\begin{array}{l}\text { parents, teachers, local community, } \\
\text { school head (advisory) }\end{array}$ & mandatory \\
\hline & participation council & grant-aided network & $\begin{array}{l}\text { organizing body, parents, teachers, } \\
\text { local community, school head }\end{array}$ & mandatory \\
\hline post-2004 & school council & all networks & $\begin{array}{l}\text { parents } \\
\text { school head (advisory) }\end{array}$ & voluntary \\
\hline & parents' council & all networks & parents & $\begin{array}{l}\text { mandatory } \\
\text { except if } \\
\text { demanded by } \\
10 \% \text { of the } \\
\text { parents }\end{array}$ \\
\hline
\end{tabular}


Table 2. Summary table of the relationship between the parents' associations and the school heads in the four schools.

\begin{tabular}{|l|c|c|c|l|}
\hline School & Parents' association & School head versus PA & School public & $\begin{array}{l}\text { Parents - school } \\
\text { relationship }\end{array}$ \\
\hline Triangle & Elite organisation & Opponents & $\begin{array}{c}\text { Middle class } \\
\text { and lower class }\end{array}$ & Dissension \\
\hline The Rainbow & Action group & Co-operators & Lower class & Partnership \\
\hline Saint-George & Friends circle & Friends & Middle class & $\begin{array}{l}\text { Domain-specific } \\
\text { partnership }\end{array}$ \\
\hline Comenius & $\begin{array}{c}\text { Formal representation } \\
\text { group }\end{array}$ & Technocratic authority & Middle class & $\begin{array}{l}\text { Domain-specific } \\
\text { partnership }\end{array}$ \\
\hline
\end{tabular}




\section{Acknowledgements}

This paper is based on data compiled within the framework of the project: "Parents and schools: partnership or struggle". The project was financed by the Research Foundation Flanders (Contract G.0116. 03).

\section{Bionotes}

Leen Dom is researcher at the Centre for Sociology of Education of the Catholic University Leuven. She is preparing a $\mathrm{PhD}$ about parent involvement in primary education. Leen Dom, Centre for Sociology of Education, University of Leuven, E. Van Evenstraat 2b, 3000 Leuven, Belgium, leen.dom@telenet.be

Jef C. Verhoeven is Professor of Sociology at the KU Leuven in Belgium and Head of the Centre for Sociology of Education of the same university. He has published in the fields of theoretical sociology and sociology of education. Over the last decade, he has conducted four projects on the relationship between parents and schools. He has recently also conducted several projects on secondary education in Belgium (amongst others, about human resource management in secondary schools and the evaluation of an equal opportunity project in Belgium). He has published several books (most in Dutch) and articles in journals such as European Journal of Education, Journal of Education Policy, Educational Management and Administration, Research on Language and Social Interaction, Teacher Development, Studies in Higher Education, Assessment in Education. Jef C. Verhoeven, Centre for Sociology of Education, University of Leuven, E. Van Evenstraat 2b, 3000 Leuven, Belgium, jef.verhoeven@soc.kuleuven.be 